\title{
Pengujian kekhususan inang parasitoid Anagyrus lopezi (De Santis) (Hymenoptera: Encyrtidae) pada empat spesies kutu putih yang berasosiasi dengan tanaman singkong
}

\author{
Host specifity test of parasitoid Anagyrus lopezi (De Santis) \\ (Hymenoptera: Encyrtidae) on four mealybug species \\ associated with cassava
}

\author{
Rani Dessy Karyani', Nina Maryana ${ }^{2}$, Aunu Rauf ${ }^{*}$ \\ ${ }^{1}$ Balai Karantina Pertanian Kelas II Cilegon, \\ Jalan Raya Transit Cikuasa, Pantai Merak, Cilegon, Banten 42438 \\ ${ }^{2}$ Departemen Proteksi Tanaman, Fakultas Pertanian, Institut Pertanian Bogor, \\ Jalan Kamper, Kampus IPB Dramaga, Bogor 16680
}

(diterima April 2015, disetujui Maret 2016)

\begin{abstract}
ABSTRAK
Parasitoid Anagyrus lopezi (De Santis) (Hymenoptera: Encyrtidae) diintroduksikan dari Thailand ke Indonesia pada awal tahun 2014, dengan maksud untuk mengendalikan kutu putih Phenacoccus manihoti Matile-Ferrero (Hemiptera: Pseudococcidae). Untuk mengetahui potensi pemanfaatan dan dampak terhadap spesies bukan sasaran dilakukan pengamatan perilaku parasitoid pada empat spesies kutu putih, yaitu P. manihoti, Paracoccus marginatus Williams-Granara de Willink, Pseudococcus jackbeardsleyi Gimpel-Miller, dan Ferrisia virgata Cockerell (Hemiptera: Pseudococcidae). Untuk maksud tersebut dilakukan uji kerentanan inang, uji preferensi inang, dan uji kesesuaian inang dengan cara memaparkan imago parasitoid pada nimfa instar-3 dari setiap spesies kutu putih di dalam cawan petri. Pada uji kerentanan inang parasitoid $A$. lopezi lebih sering mengunjungi $P$. manihoti $(13,70 \pm 7,18$ kunjungan per 30 menit) daripada P. marginatus $(9,85 \pm 10,24)$, P. jackbeardsleyi $(6,60 \pm 3,62)$, dan $F$. virgata $(5,75 \pm 4,09)$. Begitu pula penelisikan ovipositor lebih banyak terjadi pada $P$. manihoti $(8,20 \pm$ 5,68 tusukan per 30 menit) dibandingkan dengan P. marginatus $(0,70 \pm 1,84)$, P. jackbeardsleyi $(0,35$ $\pm 0,68)$, dan $F$. virgata $(0,10 \pm 0,45)$. Pada uji preferensi parasitoid lebih banyak melakukan penemuan inang dan penelisikan ovipositor pada $P$. manihoti dibandingkan dengan spesies kutu putih lainnya. Dari empat spesies kutu putih yang diuji, hanya $P$. manihoti yang merupakan inang yang sesuai bagi kehidupan parasitoid, dengan rataan banyaknya imago parasitoid yang muncul 7,40 $\pm 2,17$ individu per 3 induk parasitoid selama 24 jam pemaparan. Tingkat kekhususan inang yang diperlihatkan oleh parasitoid A. lopezi dapat menghindari terjadinya pengaruh buruk pada spesies kutu putih lain yang menghuni pertanaman singkong.
\end{abstract}

Kata kunci: Anagyrus lopezi, kekhususan inang, kutu putih, parasitoid, Phenacoccus manihoti

\begin{abstract}
A parasitoid, Anagyrus lopezi (De Santis) (Hymenoptera: Encyrtidae) was introduced from Thailand into Indonesia in early 2014 to control the cassava mealybug Phenacoccus manihoti MatileFerrero (Hemiptera: Pseudococcidae). To determine its potential uses and effect on non-target species, behavioural observation of the parasitoids were made on four species of mealybugs, i.e. P. manihoti,
\end{abstract}

\footnotetext{
*Penulis korespondensi: Aunu Rauf. Departemen Proteksi Tanaman, Fakultas Pertanian, Institut Pertanian Bogor, Kampus IPB Dramaga, Bogor 16680, Tel/Faks: 0251-8621267, Email: aunu@indo.net.id
} 
Paracoccus marginatus Williams-Granara de Willink, Pseudococcus jackbeardsleyi Gimpel-Miller, and Ferrisia virgata Cockerell (Hemiptera: Pseudococcidae). For that purposes, a set of tests were conducted wich includes host susceptability, preference, and suitability. Tests were conducted by exposing a female parasitoid to $3^{\text {rd }}$ instar nymphs of each mealybug species in a petri dish. For susceptability test, parasitoid A. lopezi encounterend P. manihoti more often $(13.70 \pm 7.18$ visits per 30 minutes) as compared to P. marginatus $(985 \pm 10.24)$, . jackbeardsleyi $(6.60 \pm 3.62)$, and F. virgata $(5.75 \pm 4.09)$. So did ovipositor probing occurred more on $P$. manihoti $(8.20 \pm 5.68$ probes per 30 minutes) than on P. marginatus $(0.70 \pm 1.84)$, $P$. jackbeardsleyi $(0.35 \pm 0.68)$, and $F$. virgata $(0.10 \pm 0.45)$. For preference test, host encounter and ovipositor probing by the parasitoid were more common on $P$. manihoti as opposed to other mealybug species. Out of four mealybug species tested, $P$. manihoti was the only suitable host for parasitoid development, with the number of progenies emerged $7.40 \pm 2.17$ individuals per 3 female parasitoids exposed in 24 hour. Host specifity exhibited by parasitoid $A$. lopezi may prevent adverse effect to other mealybug species inhabiting cassava fields.

Key words: Anagyrus lopezi, host specifity, mealybug, parasitoid, Phenacoccus manihoti

\section{PENDAHULUAN}

Kutu putih singkong, Phenacoccus manihoti Matile-Ferrero (Hemiptera: Pseudococcidae), merupakan hama yang berasal dari Amerika Selatan. Pada tahun 1973 hama ini dijumpai di Afrika Barat, dan kemudian dengan cepat menyebar ke hampir seluruh negeri di Afrika. Di beberapa lokasi, kehilangan hasil dilaporkan mencapai 82\% (Nwanze 1982; Schulthess et al. 1991). Pada tahun 2008, kutu P. manihoti ditemukan di Asia. Negara yang pertama kali melaporkan adanya serangan $P$. manihoti adalah Thailand, dengan kehilangan hasil sekitar 30\%. Di Indonesia, hama ini pertama kali ditemukan di Bogor pada tahun 2010 (Muniappan et al. 2011). Berdasarkan survei petani di Kabupaten Bogor, kehilangan hasil diperkirakan 30-50\% (Dwianri 2013; Wardani 2015).

Untuk hama eksotik semacam P. manihoti, pendekatan pengendalian yang umum dilakukan adalah dengan mengintroduksikan musuh alami dari negeri asal hama. Terdapat hal-hal penting yang perlu diperhatikan dalam mendatangkan agens pengendalian hayati ke daerah yang baru, yaitu perlunya pengetahuan tentang kekhususan inang atau kisaran inang dari suatu agens pengendalian hayati. Pengetahuan tersebut penting dalam mengevaluasi potensi penggunaannya dan memperkirakan risiko yang mungkin ditimbulkannya terhadap organisme bukan sasaran (van Lentern et al. 2003).

Anagyrus lopezi (De Santis) (Hymenoptera: Encyrtidae) merupakan parasitoid yang berasal dari Amerika Selatan, dengan inang utamanya adalah kutu putih $P$. manihoti. Setelah diintro- duksikan dari negeri asalnya ke Afrika pada tahun 1981, parasitoid A. lopezi berhasil menetap di 26 negara di Afrika dan menyebabkan penurunan serangan kutu putih pada pertanaman singkong secara signifikan (Neuenschwander 1994; Neuenschwander 2001). Pada September 2009, parasitoid A. lopezi diintroduksikan dari Benin (Afrika) ke Thailand dengan tujuan untuk mengendalikan kutu putih $P$. manihoti (Winotai et al. 2010). Di negara ini parasitoid A. lopezi berhasil menetap dan berperan dalam menurunkan serangan kutu putih. Sementara itu, sejak terdeteksinya $P$. manihoti di Indonesia pada tahun 2010, hingga kini belum dijumpai musuh alami yang mampu mengendalikan serangan $P$. manihoti (Rauf 2014). Bedasarkan pertimbangan tersebut, Departemen Proteksi Tanaman, Fakultas Pertanian-IPB bekerjasama dengan CIATVietnam dan FAO mengintroduksikan parasitoid A. lopezi dari Thailand ke Indonesia pada Maret 2014 (Wyckhuys et al. 2014).

Introduksi musuh alami yang berasal dari luar ke suatu wilayah berpotensi menimbulkan gangguan terhadap spesies lokal bukan sasaran (Sand \& van Driesche 2002). Oleh karena itu, introduksi musuh alami perlu disertai analisis risiko tentang kemungkinan munculnya dampak negatif terhadap ekosistem di kemudian hari (van Lentern et al. 2003), seperti diatur dalam International Standards for Phytosanitary Measures (ISPM) Nomor 3 tentang Kode Etik Introduksi dan Pelepasan Agens Pengendalian Hayati dan Keputusan Menteri Pertanian Republik Indonesia Nomor 411/Kpts/TP.120/6/95 tentang Pemasukan Agens Hayati ke dalam Wilayah 
Negara Indonesia. Untuk memenuhi perundangan tersebut perlu dilakukan pengujian kekhususan inang dari parasitoid $A$. lopezi.

Pengetahuan tentang kekhususan inang atau kisaran inang merupakan langkah pertama yang perlu dilakukan dalam mengevaluasi parasitoid (van Driesche \& Hoddle 1997). Sekumpulan spesies yang dimanfaatkan sebagai inang oleh suatu parasitoid di lapangan disebut kisaran inang ekologis (Onstad \& Mc Manus 1996). Kisaran inang fundamental adalah sekumpulan spesies yang diterima oleh parasitoid dan dapat mendukung perkembangan hidupnya di laboratorium (Onstad \& Mc Manus 1996). Pemilihan spesies dalam studi kisaran inang fundamental perlu didasarkan pada hubungan filogenetika antara spesies sasaran dan spesies bukan sasaran (van Klinden 2000; Kuhlmann \& Mason 2003).

Penelitian ini bertujuan untuk menentukan kerentanan, preferensi, dan kesesuaian empat spesies kutu putih sebagai inang parasitoid $A$. lopezi. Penentuan inang bukan sasaran perlu mempertimbangkan kesamaan ekologi dengan inang sasaran (Kuhlmann et al. 2006). Spesies kutu putih yang diuji dalam penelitian adalah yang umum dijumpai menyerang tanaman singkong, yaitu P. manihoti, Pseudococcus jackbeardsleyi Gimpel and Miller, Paracoccus marginatus Williams-Granara de Wilink, dan Ferrisia virgata (Cockerell) (Hemiptera: Pseudococcidae).

\section{BAHAN DAN METODE}

Penelitian dilaksanakan di Laboratorium Bionomi dan Ekologi Serangga, Departemen Proteksi Tanaman, Fakultas Pertanian, Institut Pertanian Bogor. Kegiatan penelitian dilaksanakan pada bulan Juni 2014 sampai Januari 2015.

\section{Penyiapan tanaman inang}

Penyiapan tanaman inang meliputi penanaman bibit singkong berupa stek yang ditumbuhkan di dalam ember plastik berisi air dengan campuran pupuk cair. Tanaman selanjutnya diletakkan di tempat yang cukup cahaya dan dipelihara hingga tumbuh daun pucuk baru. Setiap tiga hari sekali tanaman diisi air yang baru untuk menjaga kesegarannya.

\section{Penyiapan kutu putih}

Empat spesies kutu putih yang diuji ( $P$. manihoti, $P$. marginatus, $P$. jackbeardsleyi, dan $F$. virgata) dikumpulkan dari berbagai pertanaman singkong di lapangan, baik yang ditemukan pada bagian pucuk daun maupun batang. Bagian tanaman yang terinfestasi dipotong dan dimasukkan ke dalam kotak plastik kecil bertutup kain kasa. Selanjutnya sampel dibawa ke laboratorium untuk dilakukan identifikasi secara morfologi baik langung maupun melalui preparat slide. Identifikasi melalui preparat diperlukan untuk memastikan spesies kutu putih yang akan digunakan dalam pengujian. Pembuatan preparat dilakukan sesuai metode yang diuraikan oleh Williams (2004). Kutu putih yang digunakan terdiri atas spesies $F$. virgata, $P$. jackbeardsleyi, $P$. marginatus, dan $P$. manihoti.

\section{Perbanyakan kutu putih}

Kutu putih P. manihoti diperbanyak dan dipelihara pada tanaman singkong, P. jackbeardsleyi dipelihara pada labu parang, P. marginatus dipelihara pada tunas umbi kentang dan $F$. virgata dipelihara pada bibit tanaman jambu biji. Nimfa dan imago dari masing-masing spesies kutu putih yang diperoleh dari lapangan diinfestasikan pada masing-masing tanaman inang pemeliharaan dengan cara menempelkan langsung bagian tanaman yang mengandung koloni kutu putih atau dengan bantuan menggunakan kuas secara hatihati. Pemeliharaan dan perbanyakan $P$. manihoti pada tanaman singkong dan $F$. virgata pada bibit jambu biji, masing-masing dilakukan di dalam kurungan serangga yang berbeda pada kondisi suhu lingkungan yang teduh namun hangat. Seluruh kurungan berukuran sama $(\mathrm{p}=100 \mathrm{~cm}$, $1=50 \mathrm{~cm}, \mathrm{t}=120 \mathrm{~cm}$ ) dengan sisi-sisi berbahan kaca dan kain trikod.

Perbanyakan dan pemeliharaan spesies kutu putih lainnya dilakukan menggunakan wadah plastik bertutupkan kain kasa dan dipelihara dalam kondisi gelap di dalam laboratorium. Sekitar tiga sampai empat minggu setelah infestasi awal, nimfa instar-3 dari setiap spesies dikumpulkan dan digunakan untuk pengujian.

\section{Perbanyakan parasitoid}

Imago $A$. lopezi dimasukkan ke dalam kurungan berisi tanaman singkong yang sudah terinfestasi $P$. 
manihoti. Kurungan berukuran $50 \mathrm{~cm}$ x $45 \mathrm{~cm} \mathrm{x}$ $45 \mathrm{~cm}$, dengan pintu berlapis kain kasa berukuran sekitar $15 \mathrm{~cm}$ x $15 \mathrm{~cm}$ dan dindingnya terbuat dari bahan kain kasa dan plastik. Dalam kurungan juga digantungkan kapas yang mengandung cairan madu $10 \%$. Setiap dua minggu sekali, tanaman singkong yang sudah mengering akibat serangan kutu putih dan mengandung parasitoid dikeluarkan dari kurungan dan diganti dengan tanaman baru yang segar dan sudah terinfestasi $P$. manihoti. Tanaman singkong yang kering dipotong-potong dan dimasukkan ke dalam kotak plastik berkasa berukuran $20 \mathrm{~cm} \times 25 \mathrm{~cm}$ untuk memperoleh imago parasitoid baru. Setiap hari imago yang keluar kembali dimasukkan ke dalam kurungan pemeliharaan menggunakan aspirator dan sebagian yang masih berumur satu hari digunakan untuk pengujian. Pemeliharaan parasitoid dilakukan di dalam insektari, dengan suhu ruang $27^{\circ} \mathrm{C}$ dan $\mathrm{RH}$ $60 \%$. Kurungan berada di bawah penyinaran dua lampu neon 70 watt berjarak sekitar $20 \mathrm{~cm}$ di atas kurungan dengan lama penyinaran 12 jam gelap dan 12 jam terang.

\section{Pengujian kerentanan spesies inang (uji tanpa pilihan)}

Sepuluh kutu putih dari setiap spesies dikumpulkan dan diletakkan secara berkelompok di dalam cawan petri $(\mathrm{d}=10 \mathrm{~cm}, \mathrm{t}=1,3 \mathrm{~cm})$ yang terpisah satu sama lain. Sebelumnya setiap cawan petri diberi alas kertas tisu dan selembar daun ubi kayu sebagai pakan dari kutu putih. Selanjutnya satu individu parasitoid betina yang berumur satu hari dan sudah berkopulasi dimasukkan ke dalam setiap cawan. Secara terus-menerus selama 30 menit, cawan petri diamati dan dicatat frekuensi penemuan inang (host encounter), penelisikan ovipositor (ovipositor probing), dan perilaku pengisapan inang (host feeding) dari parasitoid. Setelah 30 menit pemaparan, parasitoid dikeluarkan dan setelah dua hari pasca pemaparan, seluruh kutu putih yang telah terpapar parasitoid dibedah di dalam setetes ringer di atas permukaan objek gelas menggunakan jarum mikro, di bawah mikroskop stereo dan dilanjutkan menggunakan mikroskop compound untuk mengamati jumlah telur atau larva parasitoid yang terdapat di dalam tubuh kutu putih. Pengujian dilakukan terhadap setiap spesies kutu putih stadia nimfa instar-3, dengan masing-masing pengujian dilakukan sebanyak 20 ulangan. Rata-rata suhu dan kelembaban relatif selama pengujian berlangsung masingmasing adalah $29,18{ }^{\circ} \mathrm{C}$ (kisaran 27,1-30,7 ${ }^{\circ} \mathrm{C}$ ) dan 57,68\% (kisaran 32-77\%).

Frekuensi penemuan inang, penelisikan ovipositor, pengisapan inang, banyaknya inang yang terparasit oleh imago A. lopezi, banyaknya telur atau larva parasitoid yang ditemukan di dalam tubuh inang digunakan sebagai kriteria untuk menentukan kerentanan spesies inang. Pengaruh perbedaan kerentanan spesies kutu putih terhadap parasitoid dianalisis dengan uji Kruskal-Wallis menggunakan progam SPSS 22.0, dan dilanjutkan dengan uji Dunn pada tingkat kepercayaan 95\%.

\section{Pengujian preferensi spesies inang (uji pilihan berpasangan)}

Pengujian preferensi $A$. lopezi dilakukan dengan cara menempatkan lima individu dari spesies $P$. manihoti yang dipasangkan dengan lima individu dari salah satu pesies kutu putih uji lainnya sehingga di dalam satu cawan petri berisi dua spesies kutu putih yang berbeda. Pengujian dilakukan juga terhadap setiap spesies kutu putih lainnya. Setiap cawan petri berisi selembar daun singkong, yang sebelumnya telah diberi alas kertas tisu. Selanjutnya satu individu parasitoid betina berumur satu hari yang sudah berkopulasi dimasukkan ke dalam cawan petri.

Secara terus-menerus selama 30 menit, setiap cawan diamati dan dicatat frekuensi penemuan inang (host encounter), penelisikan ovipositor (ovipositor probing) dan perilaku pengisapan inang (host feeding) dari parasitoid. Setelah 30 menit pemaparan, parasitoid dikeluarkan dan setelah dua hari pasca pemaparan, seluruh kutu putih yang telah terpapar parasitoid dibedah di dalam setetes ringer di atas permukaan objek gelas menggunakan jarum mikro, di bawah mikroskop stereo dan dilanjutkan menggunakan mikroskop compound untuk mengamati jumlah telur atau larva parasitoid yang terdapat di dalam tubuh kutu putih. Pengujian dilakukan terhadap setiap spesies kutu putih stadia nimfa instar-3, dengan masing-masing pengujian dilakukan sebanyak 20 ulangan. Rata-rata suhu dan kelembaban relatif 
selama pengujian berlangsung masing-masing adalah $29,25^{\circ} \mathrm{C}$ (kisaran $27,3-31,6{ }^{\circ} \mathrm{C}$ ) dan $59,9 \%$ (kisaran 43-79\%).

Frekuensi penemuan inang, penelisikan ovipositor, pengisapan inang, banyaknya inang yang terparasit oleh imago A. lopezi, banyaknya telur atau larva parasitoid yang ditemukan dalam tubuh inang digunakan sebagai kriteria dalam menentukan preferensi parasitoid terhadap inang. Perbedaan preferensi inang dianalisis dengan uji Mann-Whitney menggunakan progam SPSS 22.0 pada tingkat kepercayaan $95 \%$.

\section{Pengujian kesesuaian spesies inang}

Sebanyak masing-masing 30 individu kutu P. manihoti, F. virgata, P. jackbeardsleyi, dan $P$. marginatus diinfestasikan pada umbi kentang yang bertunas dan ditempatkan di dalam gelas plastik (d $=8 \mathrm{~cm}, \mathrm{t}=12 \mathrm{~cm}$ ) dengan bagian atasnya tertutup kain kasa. Selanjutnya tiga individu A. lopezi betina yang berumur satu hari dan sudah kopulasi dipaparkan ke dalam kurungan selama 24 jam, dan setelah itu parasitoid dikeluarkan kembali. Kutu putih dibiarkan hidup pada tunas kentang, dan diamati setiap hari. Banyaknya imago parasitoid yang muncul dan jenis kelaminnya dicatat. Pengujian dilakukan terhadap kutu putih stadia nimfa instar-3 dan dilakukan sebanyak 10 ulangan untuk setiap spesies kutu putih. Percobaan dilakukan di dalam ruangan bersuhu $27{ }^{\circ} \mathrm{C}$ dan $\mathrm{RH} 60 \%$ dengan bagian atasnya berupa lampu neon 70 watt berjarak $30 \mathrm{~cm}$ dari gelas plastik, dengan lama penyinaran 12 jam gelap dan 12 jam terang. Pengaruh perbedaan spesies kutu putih terhadap banyaknya imago parasitoid yang muncul dianalisis dengan uji Kruskal-Wallis.

\section{HASIL}

\section{Kerentanan spesies inang (uji tanpa pilihan)}

Pada percobaan tanpa pilihan terhadap empat spesies kutu putih, parasitoid A. lopezi memperlihatkan respons yang berbeda nyata dalam hal penemuan inang $(\mathrm{P}=0,002)$, penelisikan ovipositor $(\mathrm{P}<0,001)$ dan banyaknya inang terparasit $(\mathrm{P}<0,001)$ (Tabel 1). Urutan kerentanan keempat spesies kutu putih terhadap parasitoid A. lopezi, dimulai dari yang paling rentan, yaitu P. manihoti, P. marginatus, $P$. jackbeardsleyi, dan $F$. virgata. Kutu putih $P$. manihoti lebih sering $(13,70 \pm 7,18)$ dikunjungi atau ditemukan oleh parasitoid daripada kutu putih $P$. marginatus $(9,85$ $\pm 10,24)$, P. jackbeardsleyi $(6,60 \pm 3,62)$, dan $F$. virgata $(5,75 \pm 4,09$ kunjungan per 30 menit). Hal serupa terjadi pula pada penelisikan ovipositor, yaitu lebih banyak pada $P$. manihoti $(8,20 \pm 5,68$ tusukan per 30 menit), dibandingkan dengan $P$. marginatus $(0,70 \pm 1,84), P$. jackbeardsleyi $(0,35$ $\pm 0,68)$, dan $F$. virgata $(0,10 \pm 0,45)$. Penelisikan ovipositor terhadap keempat spesies kutu putih berlangsung sekitar 3-5 detik.

Tidak ada perbedaan yang nyata dari parasitoid dalam hal frekuensi pengisapan inang $(\mathrm{P}=0,094)$. Pengisapan inang sangat jarang terjadi dengan frekuensi berkisar 0,20 hingga 0,35 , dengan masa pengisapan inang berlangsung beberapa detik, dan tidak sampai menimbulkan kematian pada inangnya. Bahkan pada $F$. virgata tidak teramati adanya pengisapan inang oleh parasitoid. Permukaan tubuh $F$. virgata yang ditutupi lilin yang lebih tebal dan lengket, tampaknya menyulitkan bagi parasitoid untuk melakukan penemuan inang, penelisikan ovipositor, dan terutama pengisapan

Tabel 1. Penemuan inang, penelisikan ovipositor, pengisapan inang, dan inang terparasit oleh parasitoid Anagyrus lopezi pada pengujian kerentanan inang (uji tanpa pilihan)

\begin{tabular}{lcccc}
\hline \multirow{2}{*}{ Spesies kutu putih } & \multicolumn{4}{c}{ Rata-rata $\pm \mathrm{SD}^{*}$} \\
\cline { 2 - 5 } & Penemuan inang & Penelisikan ovipositor & Pengisapan inang & Inang terparasit \\
\hline Phenacoccus manihoti & $13,70 \pm 7,18 \mathrm{~b}$ & $8,20 \pm 5,68 \mathrm{~b}$ & $0,20 \pm 0,41 \mathrm{a}$ & $2,05 \pm 1,43 \mathrm{~b}$ \\
Paracoccus marginatus & $9,85 \pm 10,24 \mathrm{a}$ & $0,70 \pm 1,84 \mathrm{a}$ & $0,25 \pm 0,55 \mathrm{ab}$ & $0 \mathrm{a}$ \\
Pseudococcus jackberadsleyi & $6,60 \pm 3,62 \mathrm{a}$ & $0,35 \pm 0,68 \mathrm{a}$ & $0,30 \pm 0,47 \mathrm{~b}$ & $0 \mathrm{a}$ \\
Ferrisia virgata & $5,75 \pm 4,09 \mathrm{a}$ & $0,10 \pm 0,45 \mathrm{a}$ & $0 \mathrm{a}$ & $0 \mathrm{a}$ \\
$\chi^{2}$ & 14,682 & 41,152 & 6,388 & 38,344 \\
db & 3 & 3 & 3 & $<0,001$ \\
Nilai P & $<0,002$ & $<0,001$ & 0,094 & $<04$
\end{tabular}

*Nilai pada kolom yang sama yang diikuti oleh huruf yang sama tidak menunjukkan beda nyata (Uji Dunn $\alpha=5 \%$ ). Sebanyak 10 individu kutu putih untuk setiap spesies inang dipaparkan pada satu individu imago betina parasitoid selama 30 menit. 
inang. Pada beberapa kesempatan teramati adanya parasitoid yang terjerat lilin, dan parasitoid segera berupaya menjauh dari inang.

Dari empat spesies kutu putih yang diuji, hanya kutu putih $P$. manihoti yang terparasit atau diletaki telur oleh parasitoid A. lopezi. Proses peletakan telur berlangsung hanya dalam hitungan detik hingga menit. Pada salah satu pengamatan, oviposisi oleh $A$. lopezi berlangsung selama sembilan menit satu detik. Terkadang parasitoid perlu melakukan pengeboran (drilling) permukaan tubuh kutu putih beberapa kali agar berhasil meletakkan telurnya. Rataan banyaknya kutu $P$. manihoti yang terparasit selama 30 menit terpapar pada parasitoid $A$. lopezi, yaitu $2,05 \pm 1,43$ individu. Hasil pembedahan menunjukkan hanya satu butir telur atau satu individu larva dijumpai pada setiap inang yang terparasit. Tiga spesies kutu putih lainnya ( $P$. marginatus, $P$. jackbeardsleyi, $F$. virgata) sama sekali tidak terparasit, yang dibuktikan oleh tidak dijumpainya telur atau larva parasitoid di dalam tubuh kutu putih.

\section{Preferensi spesies inang(uji pilihan berpasangan)}

Berdasarkan uji pilihan berpasangan antara $P$. manihoti dan $P$. marginatus, parasitoid A. lopezi memperlihatkan perbedaan yang sangat nyata $(\mathrm{P}$ $<0,001)$ dalam hal penelisikan ovipositor dan banyaknya inang terparasit (Tabel 2). Parasitoid lebih sering melakukan penelisikan ovipositor pada kutu $P$. manihoti $(4,05 \pm 3,22$ tusukan per 30 menit) dibandingkan pada $P$. marginatus $(0,50$ $\pm 1,05)$. Hal ini ditunjukkan pula oleh rataan banyaknya inang terparasit, yaitu $1,40 \pm 0,90$ individu kutu putih per betina parasitoid selama 30 menit pada $P$. manihoti, sementara tidak ada satu pun kutu $P$. marginatus yang terparasit. Namun demikian, parasitoid A. lopezi memperlihatkan respon yang tidak berbeda nyata terhadap kutu $P$. manihoti dan $P$. marginatus dalam hal penemuan inang $(\mathrm{P}=0,201)$ dan pengisapan inang $(\mathrm{P}=0,648)$.

Perbedaan yang sangat nyata $(\mathrm{P}<0,001)$ juga terjadi dalam uji pilihan berpasangan antara $P$. manihoti dan P. jackbeardsleyi. Parasitoid lebih sering melakukan penelisikan ovipositor pada P. manihoti $(4,25 \pm 2,63$ tusukan per 30 menit $)$ daripada terhadap P. jackbeardsleyi $(0,60 \pm 0,94)$.
Rataan banyaknya inang terparasit, yaitu 1,70 $\pm 1,53$ individu kutu putih per betina parasitoid selama 30 menit pada $P$. manihoti dan tidak satu individu pun pada $P$. jackbeardsleyi. Tidak ada perbedaan yang nyata dalam hal penemuan inang $(\mathrm{P}=0,056)$ dan pengisapan inang $(\mathrm{P}=0,820)$ oleh parasitoid pada $P$. manihoti dan P. jackbeardsleyi.

Dalam uji pilihan berpasangan antara $P$. manihoti dan $F$. virgata, parasitoid A. lopezi lebih sering melakukan penelisikan ovipositor pada P. manihoti $(4,35 \pm 2,06$ tusukan per 30 menit $)$ dibandingkan dengan $F$. virgata $(0,05 \pm 0,22)$, dengan rataan banyaknya inang terparasit 1,65 $\pm 0,88$ individu kutu putih per betina parasitoid selama 30 menit dan nihil pada $F$. virgata. Berbeda dengan uji pilihan berpasangan sebelumnya, parasitoid $A$. lopezi memberikan respons penemuan yang berbeda nyata $(\mathrm{P}<0,001)$. Rataan penemuan inang pada $F$. virgata $(2,85 \pm 2,01$ kunjungan per 30 menit) jauh lebih sedikit dibandingkan dengan P. manihoti $(6,40 \pm 3,40)$. Semua perbedaan ini diperkirakan terkait dengan benang lilin yang lebih tebal dan lengket yang terdapat pada permukaan tubuh $F$. virgata, seperti disebutkan sebelumnya.

\section{Kesesuaian spesies inang}

Dari empat spesies kutu putih yang diuji, keberhasilan A. lopezi menyelesaikan perkembangan hidupnya hingga menjadi imago hanya terjadi pada inang kutu putih $P$. manihoti. Rataan masa perkembangan parasitoid dari sejak telur diletakkan hingga kemunculan imago paling cepat 14,9 hari dan paling lambat 26,4 hari. Rataan banyaknya imago parasitoid yang muncul dari $P$. manihoti, yaitu 7,40 $\pm 2,17$ individu yang berasal dari 30 individu kutu putih yang dipaparkan pada tiga individu parasitoid betina selama 24 jam. Nisbah kelamin betina terhadap jantan dari parasitoid yang muncul, yaitu $2: 5$. Sementara dari inang kutu putih $P$. marginatus, $P$. jackbeardsleyi, dan $F$. virgata tidak ada satu individu pun imago parasitoid yang muncul. Pengamatan menunjukkan ketiga spesies kutu putih ini tidak ada yang membentuk mumi, dan seluruh kutu berkembang menghasilkan keturunan yang baru. Hal ini berarti hanya $P$. manihoti yang sesuai sebagai inang parasitoid A. lopezi. 
Tabel 2. Penemuan inang, penelisikan ovipositor, pengisapan inang, dan inang terparasit oleh parasitoid Anagyrus lopezi pada pengujian preferensi inang (uji pilihan berpasangan)

\begin{tabular}{lcccc}
\hline & \multicolumn{4}{c}{ Rata-rata \pm SD } \\
\cline { 2 - 5 } Pasangan spesies kutu putih & $\begin{array}{c}\text { Penemuan } \\
\text { inang }\end{array}$ & $\begin{array}{c}\text { Penelisikan } \\
\text { ovipositor }\end{array}$ & $\begin{array}{c}\text { Pengisapan } \\
\text { inang }\end{array}$ & Inang terparasit \\
\hline Phenacoccus manihoti & $8,80 \pm 8,21$ & $4,05 \pm 3,22$ & $0,06 \pm 0,25$ & $1,40 \pm 0,90$ \\
Paracoccus marginatus & $5,95 \pm 6,80$ & $0,50 \pm 1,05$ & $0,40 \pm 1,10$ & 0 \\
$\quad 0,201$ & $<0,001$ & 0,648 & $<0,001$ \\
\hline Nilai P & $7,70 \pm 4,16$ & $4,25 \pm 2,63$ & $0,20 \pm 0,70$ & $1,70 \pm 1,53$ \\
Pseudococcus jackbeardsleyi & $5,20 \pm 3,04$ & $0,60 \pm 0,94$ & $0,20 \pm 0,52$ & 0 \\
$\quad$ Nilai P & 0,056 & $<0,001$ & 0,820 & $<0,001$ \\
\hline P. manihoti & $6,40 \pm 3,40$ & $4,35 \pm 2,06$ & 0 & $1,65 \pm 0,88$ \\
Ferrisia virgata & $2,85 \pm 2,01$ & $0,05 \pm 0,22$ & 0 & 0 \\
\multicolumn{1}{c}{ Nilai P } & $<0,001$ & $<0,001$ & 1,000 & $<0,001$
\end{tabular}

Masing-masing 5 individu kutu putih untuk setiap pasangan spesies inang dipaparkan pada satu individu imago betina parasitoid selama 30 menit.

\section{PEMBAHASAN}

Hasil penelitian menunjukkan bahwa parasitoid A. lopezi memiliki kekhususan inang, yaitu hanya memarasit kutu putih $P$. manihoti, baik pada uji tanpa pilihan maupun uji pilihan berpasangan. Tiga spesies kutu putih lainnya yang diuji sama sekali tidak diparasit. Selama pengamatan berlangsung tampak parasitoid $A$. lopezi lebih tertarik mendekati $P$. manihoti dan $P$. marginatus. Kedua spesies ini tubuhnya ditutupi lilin yang tipis, sementara $P$. jackbeardsleyi dan $F$. virgata memiliki lilin yang lebat. Menurut Vinson (1976), pemilihan dan penerimaan inang oleh parasitoid dipengaruhi oleh faktor biokimia, biofisik, dan perilaku inang.

Parasitoid A. lopezi melakukan kegiatan penemuan inang dan penelisikan ovipositor, selain terhadap P. manihoti, juga terhadap P. marginatus, P. jackbeardsleyi, dan F. virgata. Perilaku penemuan inang dicirikan oleh antena parasitoid yang disentuh-sentuhkan pada kutu putih. Perilaku parasitoid berikutnya adalah penelisikan ovipositor, yaitu kegiatan menusuk-nusukkan ovipositor ke dalam tubuh kutu putih untuk memeriksa kesesuaian inang. Bila inang dianggap sesuai maka parasitoid akan melakukan oviposisi. Keberhasilan parasitoid melakukan oviposisi merupakan salah satu faktor penting yang menyebabkan terjadinya parasitisasi, namun perilaku penelisikan ovipositor tidak selalu menandakan terjadinya peletakkan telur (Heidari \& Jahan 2000). Dalam penelitian ini, kegiatan penelisikan ovipositor oleh $A$. lopezi terjadi pada keempat spesies kutu putih yang diuji. Namun demikian, hasil pembedahan tidak menemukan adanya telur atau larva parasitoid di dalam tubuh P. marginatus, P. jackbearsdsleyi, dan $F$. virgata. Hal ini berbeda dengan yang berlangsung pada $P$. manihoti, setelah melakukan penelisikan ovipositor, parasitoid berulang kali mendatangi dan menusukkan ovipositornya untuk meletakkan telur di dalam tubuh $P$. manihoti. Kegiatan oviposisi dapat berlangsung hingga beberapa menit.

Telur parasitoid diletakkan secara bebas di dalam tubuh inang yang umumnya hanya satu butir telur per inang, namun terkadang juga terdapat dua atau lebih telur. Pada uji tanpa pilihan, parasitoid meletakkan satu butir telur per inang, namun pada uji pilihan berpasangan parasitoid meletakkan satu sampai tiga butir telur per inang. Perbedaan ini diduga karena ketersediaan inang yang lebih sedikit pada uji pilihan berpasangan dibandingkan dengan pada uji tanpa pilihan sehingga parasitoid berkesempatan meletakkan telur lagi pada inang yang sebelumnya sudah diletaki telur. Sifat superparasitisme dari parasitoid A. lopezi juga dilaporkan oleh Odebiyi \& Bokonon·Ganta (1986). Lama perkembangan A. lopezi dari sejak telur diletakkan hingga muncul imago hampir sama dengan yang dilaporkan oleh kedua peneliti tadi, yaitu sekitar 2-3 minggu.

Selama penelitian berlangsung, imago betina parasitoid A. lopezi tidak hanya memarasit kutu 
putih, tetapi juga melakukan pengisapan inang (host feeding). A. lopezi merupakan parasitoid yang bersifat sinovigenik (Iziquel et al. 1988). Pada parasitoid yang bersifat demikian, produksi dan pematangan telur sangat bergantung pada kemampuan imago betina memanfaatkan inang sebagai sumber nutrisi tambahan (Jervis \& Kidd 1986). Terdapat kecenderungan bahwa pengisapan inang oleh $A$. lopezi lebih sering terjadi pada kutu P. marginatus dan $P$. jackbeardsleyi dibandingkan dengan $P$. manihoti. Tampaknya parasitoid A. lopezi lebih memilih kutu putih yang bukan inangnya $(P$. marginatus dan $P$. jackbeardsleyi) sebagai sumber nutrisi, sementara kutu putih $P$. manihoti lebih dipilih untuk peletakan telur. Neuenschwander \& Sullivan (1987) melaporkan bahwa parasitoid A. lopezi lebih banyak melakukan pengisapan inang pada instar-1 nimfa kutu putih, sementara instar lanjut yang sesuai bagi perkembangan larva parasitoid digunakan untuk oviposisi. Pengisapan inang tidak terjadi pada $F$. virgata karena kutu putih ini memiliki lilin yang lebih lebat dan lengket.

Studi kekhususan inang yang menyeluruh perlu mencakup kisaran inang ekologis dan kisaran inang fisiologis atau fundamental (Strand \& Obrycki 1996). Kisaran inang fisiologis umumnya lebih lebar daripada kisaran inang ekologis karena yang disebut belakangan ini dipengaruhi oleh ketersediaan inang, perilaku parasitoid dan iklim (Haye et al. 2005). Dalam penelitian tidak dilakukan uji kisaran inang terhadap kutu putih yang menyerang tanaman selain singkong. Berdasarkan uji kisaran inang ekologis, hanya kutu putih $P$. manihoti yang menjadi inang parasitoid A. lopezi. Kutu putih lainnya, yaitu $P$. marginatus, $P$. jackbeardsleyi, dan $F$. virgata bukan inang parasitoid $A$. lopezi, akan tetapi memengaruhi perilaku pencarian inang bagi A. lopezi. Di negeri asalnya dilaporkan bahwa $A$. lopezi dapat memarasit kutu Phenacoccus herreni Cox-William dan Phenacoccus parvus Morrison (Noyes \& Hayat 1994) dan Phenacoccus gossypii Townsend-Cockerell (CABI 2008).

Keberadaan inang alternatif sangat penting bagi keberhasilan pengendalian hayati karena dapat menjaga populasinya pada saat inang utamanya sangat jarang atau tidak ditemukan di lapangan (DeBach \& Bartlett 1964). Sifat kekhususan inang dari A. lopezi menimbulkan risiko terjadinya kepunahan lokal parasitoid pada saat populasi kutu P. manihoti sangat rendah. Bila hal ini terjadi maka diperlukan upaya augmentasi dengan cara melepaskan populasi parasitoid yang berasal dari hasil pembiakan massal di laboratorium.

Sifat kekhususan inang dari A. lopezi juga menimbulkan hambatan dalam hal peluang menyediakan inang alternatif untuk keperluan pembiakan massal parasitoid. Pembiakan massal parasitoid A. lopezi hanya dapat dilakukan pada kutu P. manihoti. Seperti kebanyakan kutu putih, P. manihoti dapat diperbanyak pada tunas kentang di laboratorium. Namun demikian, hasil penelitian selama ini menujukkan bahwa media pembiakan inang berpengaruh terhadap parasitoid. Parasitoid A. lopezi yang keluar dari P. manihoti yang dipelihara pada tunas kentang berukuran lebih kecil dibandingkan yang dipelihara pada bibit singkong. Panjang tubuh $A$. lopezi pada kentang dan bibit singkong berturut-turut $1,26 \pm 0,31$ dan $1,75 \pm$ $0,21 \mathrm{~mm}$, sedangkan panjang tibia $0,37 \pm 0,14$ dan 0,47 $\pm 0,08 \mathrm{~mm}$ (Karyani 2015). Sagarra et al. (2001) medapatkan korelasi positif antara panjang tibia belakang dan berbagai parameter kebugaran parasitoid Anagyrus kamali Moursi (Hymenoptera: Encyrtidae) yang meliputi lama hidup, keperidian, banyaknya keturunan yang muncul, dan nisbah kelamin. Dalam penelitian yang kami lakukan, keturunan parasitoid yang muncul dari koloni $P$. manihoti yang dipelihara pada bibit singkong hampir dua kali lebih banyak dibandingkan dengan yang dipelihara pada tunas kentang. Begitu pula persentase betina lebih banyak pada yang disebut pertama. Hal ini mengindikasikann bahwa pembiakan massal parasitoid A. lopezi sebaiknya menggunakan bibit singkong sebagai inang kutu P. manihoti. Selain mudah didapat, harga stek singkong jauh lebih murah daripada umbi kentang.

Hambatan lain yang muncul akibat sifat kekhususan inang adalah terbatasnya peluang pemanfaatan parasitoid ini untuk mengendalikan spesies kutu putih yang lain. Namun demikian, dari segi pelestarian biodiversitas, sifat kekhususan inang ini merupakan sesuatu yang menguntungkan karena parasitoid tersebut tidak akan menimbulkan risiko terhadap spesies bukan sasaran. Dengan sifat kekhususan inang yang tinggi, hanya memarasit $P$. manihoti, kehadiran parasitoid $A$. lopezi tidak akan menimbulkan persaingan dengan spesies musuh 
alami yang sudah ada sehingga diharapkan dapat memelihara dan meningkatkan keanekaragaman hayati musuh alami di agroekosistem.

\section{KESIMPULAN}

Parasitoid A. lopezi memperlihatkan tingkat kekhususan inang yang tinggi. Dari empat spesies kutu putih yang diuji, A. lopezi hanya memarasit hama sasaran, yaitu kutu putih $P$. manihoti. Dengan demikian, pelepasan parasitoid ini di lapangan diperkirakan tidak akan menimbulkan pengaruh buruk terhadap spesies kutu putih lain yang menghuni pertanaman singkong. Pada saat yang bersamaan, ketiadaan inang alternatif dapat menyulitkan parasitoid dalam mempertahankan kehidupannya, pada saat populasi kutu putih $P$. manihoti sangat rendah di lapangan. Dari segi pembiakan massal, ketiadaan inang alternatif mengharuskan pembiakan parasitoid A. lopezi dilakukan hanya pada kutu $P$. manihoti.

\section{UCAPAN TERIMA KASIH}

Penelitian ini merupakan bagian dari proyek CIAT-Asia "Emerging Pests and Diseases of Cassava in Southeast Asia: Seeking eco-efficient solutions to overcome a threat to livelihoods and industries". Ucapan terima kasih disampaikan kepada Dr. KAG Wyckhuys (CIAT-Asia), Dr. J Ketelaar (FAO-Bangkok), Dr. Amporn Winotai (DOA-Thailand) dan Dr. Antarjo Dikin (Pusat Karantina Tumbuhan) yang telah memberikan fasilitas, dukungan, dan bantuan dalam introduksi parasitoid dari Thailand ke Indonesia.

\section{DAFTAR PUSTAKA}

CABI. 2008. Data sheet invasive species compendium: Epidinocarsis lopezi. Available at: http:// www.cabi.org/isc/datasheet/21498. [accesed 15 April 2014].

DeBach P, BartlettBR. 1964. Methods of colonization, recovery and evaluation. In: DeBach P (Eds.), Biological Control of Insect Pests and Weeds. pp. 402-426. London: Chapman \& Hall.

Dwianri I. 2013. Praktek Budi Daya dan Persepsi Petani Ubi Kayu terhadap Hama Kutu Putih
Phenacoccus manihoti di Kabupaten Bogor. Skripsi. Bogor: Institut Pertanian Bogor.

Haye T, Goulet H, Mason PG, Kuhlmann U. 2005. Does fundamental host range match ecological host range? A restrospective case study of a Lygus plant bug parasitoid. Biological Control 35:55-67. doi: http://dx.doi.org/10.1016/j.bio control.2005.06.008.

Heidari M, Jahan M. 2000. A study of ovipositional behaviour of Anagyrus pseudococci a parasitoid of mealybugs. Journal Agriculture Science and Technology 2:49-53.

Iziquel Y, Le Ralec A, Nenon JP. 1988. Epidinocarsis lopezi (Hymenoptera: Encyrtidae): ovipositeur, types de piqures et nature du parasitisme sur Phenacoccus manihoti (Homoptera: Pseudococcidae). Le Naturaliste Canadien (Revue d'Ecologie et de Systematique) 115:107-121.

Jervis MA, Kidd NAC. 1986. Host-feeding strategies in Hymenopteran parasitoids. Biology Reviews 61:395-434. doi: http://dx.doi.org/10.1111/j.14 69-185X.1986.tb00660.x.

Karyani RD. 2015. Pengujian Kesesuaian Inang Parasitoid Anagyrus Lopezi De Santis (Hymenoptera: Encyrtidae) terhadap Kutu Putih yang Berasosiasi dengan Ubi Kayu (Manihotesculenta Crantz). Tesis. Bogor: Institut Pertanian Bogor.

Kuhlmann U, Mason PG. 2003. Use of field host range surveys for selecting candidate non-target species for physiological host specifity testing of entomophagous biological control agents. In: van Driesche RG (Ed.), Proceedings of the $1^{\text {st }}$ International Symposium on Biological Control of Arthropods, Honolulu, Hawaii, (Hawai, 1418 January 2002). pp. 370-377. Morgantown: USDA, Forest Service. doi: http://dx.doi. org/10.1079/9780851990583.0015.

Kuhlmann U, Schaffner U, Mason PG. 2006. Selection of non-target species for host specificity testing. In: Bigler F, Babendreier D, Kuhlmann U (Eds.), Environmental Impact of Invertebrates for Biological Control of Arthropods. pp. 15-37. Wallingford: CABI Publishing.

Muniappan R, Shepard BM, Watson GW, Carner GR, Rauf A, Sartiami D, Hidayat P, Afun JVK, Goergen G, Rahman AKMZ. 2011. New records of invasive insects (Hemiptera: Sternorrhyncha) in southern Asia and West Africa. Journal of Agricultural and Urban Entomology 26:167174. doi: http://dx.doi.org/10.3954/1523-547526.4.167.

Neuenschwander P. 1994. Control of the cassava mealybug in Africa: Lessons from a biological control project. African Crop Science Journal 
2:369-383. doi: http://dx.doi.org/10.1006/bcon. 2001.0937.

Neuenschwander P. 2001. Biological control of the cassava mealybug in Africa: A review. Biological Control 21:14-229.

Neuenschwander P, Sullivan D. 1987. Interactions between the endophagous parasitoid Epidinocarsis lopezi and its host, Phenacoccus manihoti. Insect Science and its Application 8:857-859.

Noyes JS, Hayat M. 1994. Oriental mealybug parasitoids of the Anagyrini (Hymenoptera: Encyrtidae). Wallingford: CABI Publishing.

Nwanze KF. 1982. Relationship between cassava root yields and crop infestations by the mealybug, Phenacoccus manihoti. Tropical Pest Management 28:27-32. doi: http://dx.doi.org/10. 1080/09670878209370669.

Odebiyi JA, Bokonon·Ganta AH. 1986. Biology of Epidinocarsis (=Apoanagyrus) lopezi (Hymenoptera: Encyrtidae) an exotic parasite of cassava mealybug, Phenacoccus manihoti (Homoptera: Pseudococcidae) in Nigeria. Entomophaga 31:251-260. doi: http:/doi.org/10. 1007/BF02373334.

Onstad DW, Mc Manus ML. 1996. Risks of host range expansion by parasites of insects. BioScience 46:430-435. doi: http://dx.doi.org/ $10.2307 / 1312877$.

Rauf A. 2014. Usulan pemasukan parasitoid Anagyrus lopezi untuk pengendalian hayati kutu putih singkong, Phenacoccus manihoti. Bogor: Departemen Proteksi Tanaman, Fakultas Pertanian-IPB.

Sagarra LA, Vincent C, Stewart RK. 2001. Body size as an indicator of parasitoid quality in male and female Anagyrus kamali (Hymenoptera: Encyrtidae). Bulletin of Entomological Research 91:363-367. doi: http://dx.doi.org/10.1079/BER 2001121.

Schulthess F, Baumgartner JU, Delucchi V, Guttierez AP. 1991. The influence of the cassava mealybug, Phenacoccus manihoti Mat-Ferr (Homoptera: Pseudococcidae) on yield formation of cassava, Manihot esculenta Crantz. Journal of Applied
Entomology 111:155-165. doi: http://dx.doi.org/ 10.1111/j.1439-0418.1991.tb00306.x.

Strand MR, Obrycki JJ. 1996. Host specifity of insect parasitoids and predators. BioScience 46:422429. doi: http://dx.doi.org/10.2307/1312876.

van Driesche RG, Hoddle M. 1997. Should arthropod parasitoids and predators be subject to host range testing when used as biological control agents. Agriculture and Human Values 14:211-226. doi: http://dx.doi.org/10.1023/A:1007404710817.

van Klinden RD. 2000. Host specifity testing: Why do we do it and how can we do it better. In: van Driesche RG, Heard TA, McClay A, Reardon R (Eds.), Proceedings of Session: Host-Specifity Testing of Exotic Arthropod Biological Control Agents - the Biological Basis for Improvement in Safety, (Montana, 4-14 July 1999). pp. 5468. Morgantown: USDA, Forest Service, Forest Health Technology Enterprise Team.

van Lentern JC, Babendreier D, Bigler F, Burgio G, Hokkanen HMT, Kurke S, Loomans AJM, Menzler-Hokkanen, van Rijn PCJ, Thomas MB, Tommasini MG, Zeng QQ. 2003. Environmental risk assessment of exotic natural enemies used in inundative biological control. Biological Control 48:3-38.

Vinson SB. 1976. Host selection by insect parasitoids. Annual Review of Entomology 21:109-133. doi: http://dx.doi.org/10.1146/annurev.en.21.0101 76.000545 .

Wardani N. 2015. Kutu Putih Ubi Kayu, Phenacoccus manihoti Matile-Ferrero (Hemiptera: Pseudococcidae), Hama Invasif Baru di Indonesia. Disertasi. Bogor: Institut Pertanian Bogor.

Williams DJ. 2004. Mealybugs of Southern Asia. London: The Natural History Museum.

Winotai A, Goergen G, Tamo M, Neuenschwander P. 2010. Cassava mealybug has reached Asia. Biocontrol News and Information 31:10-11.

Wyckhuys KAG, Rauf A, Ketelaar J. 2014. Parasitoids introduced into Indonesia: part of a region-wide campaign to tackle emerging cassava pests and diseases. Biocontrol News and Information $35: 35 \mathrm{~N}-38 \mathrm{~N}$. 